\title{
Hubungan Kondisi Lingkungan Fisik dengan Kejadian Demam Berdarah Dengue di Wilayah Kerja Puskesmas Kalasan Kabupaten Sleman
}

\author{
Sucinah Wijirahayu ${ }^{1,}$, Tri Wahyuni Sukesi ${ }^{1}$ \\ ${ }^{1}$ Fakultas Kesehatan Masyarakat Universitas Ahmad Dahlan \\ *Coresponding author : yunisukesi.fkmuad@gmail.com
}

Info Artikel : Diterima November 2018 ; Disetujui Maret 2019 ; Publikasi April 2019

\begin{abstract}
ABSTRAK
Latar Belakang: Salah satu penyakit berbasis lingkungan yaitu Demam Berdarah Dengue yang sampai saat ini menjadi masalah kesehatan masyarakat dikarenakan penyebaran penyakit ini yang begitu cepat dan berpotensi menimbulkan kematian. Penyakit ini disebabkan oleh salah satu dari 4 virus dengue yang berbeda, cara penularan penyakit DBD ini melalui gigitan nyamuk Aedes aegypti. Penularan penyakit DBD dapat dipengaruhi dari faktor lingkungan yang meliputi lingkungan fisik, kimia dan biologi. Kondisi lingkungan fisik, keadaan suatu rumah juga mempengaruhi dalam penyebaran penyakit DBD ini. Tujuan dari penelitian ini adalah untuk mengetahui hubungan kondisi fisik rumah dengan kejadian DBD.

Metode: Penelitian ini bersifat analitik observasional dengan menggunakan rancangan penelitian case control study, subyek penelitian yaitu 8 kasus dan 24 kontrol. Sampel untuk kontrol ditentukan dengan teknik purposive sampling. Instrumen penelitian menggunakan lembar observasi. Analisis data menggunakan uji Chi-square dan fisher exact sebagai uji alternatif.

Hasil: Ada hubungan antara ventilasi dengan $p$ value $(\mathrm{p}=0,039)$ dan nilai $(\mathrm{OR}=0,072, \mathrm{CI}=0,006-0,849)$, Tidak ada hubungan antara kelembaban dengan nilai $p$ value $(\mathrm{p}=0,642)$ dan nilai $(\mathrm{OR}=0,347, \mathrm{CI}=0,036-3,367)$ dan $\mathrm{Ada}$ Hubungan antara pencahayaan dengan nilai $p$ value $(\mathrm{p}=0,039)$ dan nilai $(\mathrm{OR}=0,072, \mathrm{CI}=0,006-0,849)$ dengan kejadian demam Berdarah dengue di wilayah kerja Puskesmas Kalasan Kabupaten Sleman.

Simpulan: Ada hubungan yang signifikan antara ventilasi berkasa dan pencahayaan, sedangkan tidak ada hubungan yang signifikan antara kelembaban dengan kejadian demam Berdarah dengue di wilayah kerja Puskesmas Kalasan Kabupaten Sleman.
\end{abstract}

Kata kunci: Ventilasi; Kelembaban; Pencahayaan; DBD

\section{ABSTRACT}

Title : Relationship between Physical Environmental Condition and the incidence of dengue hemorrhagic fever in the working area of Kalasan Health Center, Sleman Regency

Background: Transmission of DHF can be influenced by several factors, namely environmental factors which include the physical, chemical and biological environment. The condition of the physical environment, the condition of a house also affects the spread of dengue disease. The purpose of this study was to determine the relationship between the physical condition of the house and the incidence of DHF.

Methods: This research was based on the observational analytic using a case control study design, the research subjects were 32 samples with purposive sampling technique. The research instrument were observation sheets. Data analysis used Chi-square test and fisher exact as an alternative test.

Results: There was a relationship between ventilation and $p$ value $(p=0.039)$ and value $(O R=0.072, C I=$ 0.006-0.849), there weren't relationship between humidity and $p$ value $(p=0.642)$ and value $(O R=0.347, C I=$ 0.036-3.336) and there was a relationship between lighting with $p$ value $(p=0.039)$ and value $(O R=0.072, C I$ $=0.006-0.849)$ with the incidence of dengue hemorrhagic fever in Kalasan Public Health Center Working Area at Sleman Regency. 
Conclusion: There was significant relationship between ventilation and lighting, while there wasn't significant relationship between humidity and the incidence of dengue hemorrhagic fever in Kalasan Public Health Center Working Area at Sleman Regency.

Keywords: ventilation; humidity and lighting; DHF

\section{PENDAHULUAN}

Salah satu penyakit berbasis lingkungan yaitu Demam Berdarah Dengue. Penyakit Demam Berdarah Dengue merupakan salah satu penyakit menular yang sampai saat ini menjadi masalah kesehatan masyarakat yang sering menjadi Kejadian Luar Biasa (KLB) dikarenakan penyebaran penyakit ini yang begitu cepat dan berpotensi meninmbulkan kematian. Penyakit ini disebabkan oleh salah satu dari 4 virus dengue yang berbeda, yang mana cara penularan penyakit DBD ini melalui gigitan nyamuk Aedes aegypti. ${ }^{1}$

Kasus DBD terjadi pada tahun 1953 di negara Filipina, disusul megara Thailand dan Vietnam ${ }^{2}$. Pada tahun 1970 hanya 9 negara yang mengalami wabah DBD, namun sekarang DBD telah endemik pada 100 negara salah satunya indonesia ${ }^{1}$. Sejak tahun 1968 hingga tahun 2009, WHO mencatat Indonesia merupakan negara dengan kasus tertinggi di Asia Tenggara $^{2}$. Pada tahun 2016, tercatat jumlah kasus DBD di Indonesia sebanyak 204.171 dengan jumlah kematian sebanyak 1.589 orang. Kasus DBD pada tahun 2016 ini mengalami peningkatan dibandingkan pada kasus DBD pada tahun 2015 yaitu sebanyak 129.650 kasus. $^{3}$

Pada dasarnya penularan penyakit DBD ini terjadi dikarenakan adanya penderita maupun pembawa virus dengue. Kejadian DBD terjadi karena adanya faktor pemicu seperti pendidikan, keadaan sosial ekonomi, pengetahuan, imunitas, kelembaban udara, curah hujan, keadaan sanitasi lingkungan. ${ }^{4}$ Penularan penyakit DBD yang paling bepengaruh yaitu dilihat dari faktor lingkungan yang meliputi lingkungan fisik, kimia dan biologi. Lingkungan sangat berperan dalam distribusi keberadaan organisme vektor dari penyakit berbasis lingkungan. ${ }^{5}$

Selain kondisi lingkungan fisik, keadaan suatu rumah juga mempengaruhi dalam penyebaran penyakit DBD ini. Keadaan lingkungan fisik rumah yang tidak memenuhi syarat memberikan peluang yang besar terhadap terjadinya penyakit DBD. Kondisi lingkungan fisik rumah yang dimaksud yaitu ventilasi berkasa, kelembaban, dan pencahayaan. Ventilasi merupakan suatu bangunan rumah yang mana selain sebagai tempat sirkulasi udara dan sebagai tempat masuknya cahaya. Secara teori rumah yang tidak sehat dapat menimbulkan berbagai macam penyakit apabila rumah tersebut tidak memiliki ventilasi yang memadai. Keadaan rumah dengan kondisi ventilasi yang tidak terpasang kasa nyamuk akan memudahkan nyamuk untuk masuk dan mengigit manusia yang ada di dalam rumah. ${ }^{6}$ Kegunaan vemtilasi lainnya untuk menjaga stabilitas suhu tubuh, mengatur suhu ruang dan juga dapat mengurangi kelembaban dan sebagai tempat pencahayaan masuk kedalam ruangan rumah. Kelembaban suatu ruangan juga berisiko untuk perkembangan biakan nyamuk Aedes aegypti. ${ }^{4}$ Karena kelembaban merupakan salah satu kondisi lingkungan yang mana dapat mempengaruhi perkembangan jentik nyamuk dan umur nyamuk karena seperti yang diketahui sistem pernafasan nyamuk menggunakan pipa-pipa udara. Kelembaban udara yang optimal untuk ketahanan nyamuk untuk berkembang biak sekitar $81,5 \%$ hingga $89,5 \% .^{7}$ Pencahayaan seperti yang diketahui nyamuk menyukai tempat yang memiliki pencahayaan yang minim yaitu kurang dari 60 lux dan menjadikan tempat yang minim cahaya tersebut sebagai tempat istirahatnya dan mempengaruhi aktifitas nyamuk tersebut. ${ }^{6}$

Pada penelitian ini variabel yang digunakan adalah kondisi lingkungan fisik rumah yang meliputi ventilasi berkasa, kelembaban, dan pencahayaan. Penelitian ini bertujuan untuk mengetahui kondisi ventilasi berkasa, kelembaban, pencahayaan dan hubungan kondisi lingkungan fisik dengan kejadian demam berdarah Dengue di wilayah kerja Puskesmas Kalasan Kabupaten Sleman. Selanjutnya untuk mengetahui hubungan antara kondisi lingkungan fisik rumah dengan kejadian Demam Berdarah Dengue di wilayah kerja Puskesmas Kalasan Kabupaten Sleman dapat dilakukan uji Chi-square dan menggunakan uji fisher exact sebagai uji alternatif dengan instrumen yang digunakan yaitu lembar observasi.

\section{MATERI DAN METODE}

Penelitian imi bersifat analitik observasional dengan menggunakan rancangan penelitian Case Control, yaitu suatu rancangan penelitian yang membandingkan antara kelompok kasus dengan kelompok kontrol untuk mengetahui proporsi kejadian berdasarkan riwayat ada tidaknya paparan ${ }^{8}$. Subyek yang digunakan sebanyak 32 sampel dengan pebandingan kasus kontrol adalah 8 kasus dan 24 kontrol. pengambilan sampel menggunakan purposive sampling yaitu teknik penentuan sampel dengan beberapa pertimbangan. ${ }^{9}$ Untuk pengambilan sampel kasus diperoleh dari data Puskesmas Kalasan untuk bulan Agustus 2018 sedangkan untuk menentukan kontrol dilakukan proses matching antara subyek yang kasus dengan subyek yang kontrol. Instrumen yang digunakan yaitu lembar observasi dan check list. Pada penelitian ini variabel yang digunakan adalah kondisi lingkungan fisik rumah yang meliputi ventilasi berkasa, kelembaban, dan pencahayaan. Selanjutnya untuk mengetahui hubungan antara kondisi lingkungan fisik rumah dengan kejadian Demam Berdarah Dengue di wilayah kerja Puskesmas Kalasan Kabupaten 
Sleman dapat dilakukan uji Chi-square dan menggunakan uji fisher exact sebagai uji alternatif dengan instrumen yang digunakan yaitu lembar observasi.

\section{HASIL DAN PEMBAHASAN}

Tabel 1. Hasil Uji Univariat Kondisi Lingkungan Fisik Rumah (Ventilasi Berkasa, Kelembaban, Pencahayaan) dengan Kejadian DBD Di Wilayah Kerja Puskesmas Kalasan Kabupaten Sleman Tahun 2018

\begin{tabular}{|c|c|c|}
\hline \multirow[t]{2}{*}{ Variabel } & \multicolumn{2}{|c|}{ Responden } \\
\hline & n (orang) & $\%$ \\
\hline \multicolumn{3}{|l|}{ Kejadian DBD } \\
\hline Kasus & 8 & 25,0 \\
\hline Kontrol & 24 & 75,0 \\
\hline \multicolumn{3}{|l|}{ Ventilasi Berkasa } \\
\hline Tidak ventilasi tidak berkasa & 28 & 87,5 \\
\hline Iya ventilasi berkasa & 4 & 12,5 \\
\hline \multicolumn{3}{|l|}{ Kelembaban } \\
\hline Memenuhi syarat & 8 & 25,0 \\
\hline Tidak memenuhi syarat & 24 & 75,0 \\
\hline \multicolumn{3}{|l|}{ Pencahayaan } \\
\hline Memenuhi syarat & 28 & 87,5 \\
\hline Tidak memenuhi syarat & 4 & 12,5 \\
\hline Total & 32 & 100 \\
\hline
\end{tabular}

Analsis bivariat digunakan untuk mengetahui masingmasing hubungan antara variabel bebas dan variabel terikat. Uji statistik yang digunakan adalah chi square dengan kemaknaan $\mathrm{p}<0,05$.

1) Hubungan antara ventilasi berkasa dengan kejadian Demam Berdarah Dengeu di Wilayah Kerja Puskesmas Kalasan Kabupaten Sleman

Pada Tabel 2. menunjukan bahwa kondisi rumah responden yang menderita DBD (kasus) lebih banyak memiliki ventilasi tidak berkasa yaitu 5 responden $(62,5 \%)$ dibandingkan dengan yang ventilasi menggunakan kasa yaitu 3 responden $(37,5 \%)$. Begitu juga dengan kondisi rumah responden yang tidak menderita DBD (kontrol) banyak yang ventilasinya tidak menggunakan kasa yaitu 23 responden $(95,8 \%)$ dibandingkan dengan yang ventilasi menggunakan kasa yaitu 1 responden (4,2\%). Hasil uji statistik fisher diperoleh hasil analisis bivariat dengan nilai $\mathrm{p}<0,05$ yaitu 0,039 yang artinya ada hubungan yang bermakna secara statistik antara variabel berkasa dengan kejadian DBD. Nilai $\mathrm{OR}=0,072$ dengan $\mathrm{CI}$ $95 \%(0,006-0.849)$ yang artinya ventilasi berkasa belum tentu merupakan faktor risiko terhadap kejadian DBD. Risiko terjadinya penyakit DBD pada kondisi ventilasi rumah responden yang tidak menggunakan kasa nyamuk sebesar 0,072 kali lebih besar dibandingkan dengan kondisi ventilasi rumah responden yang menggunakan kasa nyamuk.

Tabel 2. Hasil Analisis Bivariat Hubungan Ventilasi Berkasa dengan Kejadian Demam Berdarah Dengue Di Wilayah Kerja Puskesmas Kalasan Kabupaten Sleman Tahun 2018

\begin{tabular}{lllllllr}
\hline \multirow{2}{*}{ Ventilasi Berkasa } & \multicolumn{4}{c}{ DBD } & \multicolumn{2}{c}{ Total } \\
\cline { 2 - 7 } & \multicolumn{3}{c}{ Kasus } & \multicolumn{1}{c}{ Kontrol } & \\
\cline { 2 - 7 } & & $\mathbf{n}$ & $\mathbf{\%}$ & $\mathbf{n}$ & $\mathbf{\%}$ & $\mathbf{n}$ & $\mathbf{\%}$ \\
\hline Tidak ventilasi tidak berkasa & 5 & 62,5 & 23 & 95,8 & 28 & 87,5 \\
Iya ventilasi berkasa & 3 & 3,5 & 1 & 4,2 & 4 & 12,5 \\
\hline Jumlah & 8 & 100 & 24 & 100 & 32 & 100 \\
\hline p-value $=0,039$ OR $=0,072$ & & & & & & &
\end{tabular}

Hasil penelitian ini sejalan dengan penelitian Ayun dan Pawenang dengan hasil nilai $\mathrm{p}=0,024$ yang berarti ada hubungan antara ventilasi berkasa dengan kejadian DBD di wilayah kerja Puskesmas Sekaran Kecamatan Gunungpati Kota Semarang tahun 2015. ${ }^{10}$ Namum berbeda dengan penelitian Sari dkk didapatkan nilai $\mathrm{p}=0,330$ yang artinya tidak ada hubungan ventilasi berkasa dengan kejadian DBD di Semarang. ${ }^{11}$

Berdasarkan penelitian yang telah dilakukan di wilayah kerja Puskesmas Kalasan menunjukan bahwa kondisi ventilasi berkasa rumah responden yang menderita DBD dengan yang tidak menderita DBD sebagian rumah ada yang dipasang kasa nyamuk, namun sebagian besar responden 
kebanyakan ventilasi rumahnya tidak menggunakan kasa nyamuk. Keberadaan ventilasi pada suatu bangunan selain untuk pencahayaan juga digunakan sebagai tempat pertukaran udara ${ }^{11}$ dan ventilasi dapat dimanfaatkan oleh vektor untuk keluar masuk ke dalam rumah. Kasa nyamuk atau kawat kasa merupakan salah satu alat pelindung yang terbuat dari besi yang dipasangkan pada ventilasi. Pemakaian kasa pada ventilasi yaitu sebagai salah satu upaya pencegahan penularan penyakit DBD yang mana penggunaan kasa ini bertujuan agar nyamuk tidak dapat masuk ke dalam rumah dan menggigit manusia. Selain penggunaan kasa nyamuk pada ventilasi beberapa kebiasaan masyarakat dilapangan yang juga menjadi faktor penyebaran vektor DBD yaitu kebiasaan membuka pintu dan jendela di pagi-siang hari. Untuk mencegah masuknya vektor DBD sebaiknya ventilasi dilapisi dengan kasa nyamuk serta tidak membuka pintu dan jendela sehingga kemungkinan nyamuk untuk masuk ke dalam rumah dan mengigit manusia akan semakin kecil.

2) Hubungan antara kelembaban dengan kejadian Demam Berdarah Dengue di wilayah kerja Puskesmas Kalasan Kabupaten Sleman

Tabel 3. Hasil Analisis Bivariat Hubungan Kelembaban dengan Kejadian Demam Berdarah Dengue Di Wilayah Kerja Puskesmas Kalasan

\begin{tabular}{lllllll}
\hline \multirow{2}{*}{$\begin{array}{l}\text { Kelembab } \\
\text { an }\end{array}$} & \multicolumn{4}{c}{ DBD } & \multicolumn{2}{c}{ Total } \\
\cline { 2 - 5 } & \multicolumn{2}{c}{ Kasus } & \multicolumn{2}{c}{ Kontrol } & & \\
\cline { 2 - 6 } & $\mathbf{N}$ & $\mathbf{\%}$ & $\mathbf{N}$ & $\mathbf{\%}$ & $\mathbf{n}$ & $\mathbf{\%}$ \\
\hline $\begin{array}{l}\text { Memenuhi } \\
\text { syarat }\end{array}$ & 1 & 12,5 & 7 & 29,2 & 8 & 25 \\
$\begin{array}{l}\text { Tidak } \\
\text { memenuhi } \\
\text { syarat }\end{array}$ & 7 & 87,5 & 17 & 70,8 & 24 & 75 \\
\hline Jumlah & 8 & 100 & 24 & 100 & 32 & 100 \\
\hline p-value $=0,642$ & OR $=0,347$ & & &
\end{tabular}

Pada Tabel 3. menunjukan bahwa kondisi kelembaban udara rumah responden yang menderita DBD (kasus) lebih banyak tidak memenuhi syarat perkembangbiak dan pertumbuhan dari vektor penyakit DBD yaitu 7 responden $(87,5 \%)$ dibandingkan dengan kondisi kelembaban udara memenuhi syarat perkembangbiakan dan pertumbuhan dri vektor penyakit DBD yaitu 1 responden (12,5\%). Begitu juga dengan kondisi kelembaban udara rumah responden yang tidak menderita DBD (kontrol) banyak yang tidak memenuhi s

yarat perkembangbiak dan pertumbuhan vektor yaitu 17 responden $(70,8 \%)$ dibandingkan dengan kondisi kelembaban udara rumah yang memenuhi syarat perkembangbiakan dan pertumbuhan vektor yaitu 7 responden $(29,2 \%)$. Hasil uji statistik fisher diperoleh hasil analisis bivariat dengan nilai $\mathrm{p}>$
0,05 yaitu 0,642 yang artinya tidak ada hubungan yang bermakna secara statistik antara variabel kelembaban dengan kejadian DBD. Nilai $\mathrm{OR}=$ 0,347 dengan CI 95\% (0,036-3,367) yang artinya kelembaban belum tentu merupakan faktor risiko terjadap kejadian DBD. Hasil dari kondisi kelembaban dipengaruhi dari ketinggian tempat, kerapatan angin,suhu,radiasi matahari. Selain itu kelembaban pada suatu daerah yang datarannya rendah dengan yang datarannya tinggi akan berbeda. Kecamatan kalasan merupakan suatu daerah yang berada pada daratan rendah yang mana disekitarnya masih dikelilingi sawah serta banyak terdapat pepohonan dan pada beberapa rumah responden yang diteliti pada halaman rumahnya diletakkan tanaman hias serta kebiasaan responden membuka pintu dan jendela pada pagi-siang hari yang merubah tingkat kelembaban di rumah responden tersebut. Hal ini menyebabkan kemaknaan secara biologis atau besarnya risiko OR yang didapat yaitu 0,347 yang berarti kelembaban belum tentu faktor risiko dari kejadian DBD.

Kondisi kelembaban udara didalam suatu ruangan dipengaruhi oleh beberapa hal seperti musim, kondisi udara luar, kondisi ruangan yang kebanyakan merupakan ruangan yang minim dengan ventilasi. ${ }^{14}$ Seperti yang diketahui kelembaban adalah banyaknya uap air yang terkandung dalam udara yang dinyatakan dalam persen. Kelembaban optimum pada suatu ruangan adalah 40\%-60\%. Untuk perkembangbiakan nyamuk kelembaban udara yang baik berkisar dari $60 \%-80 \% .15$

Tidak adanya hubungan yang signifikan antara kelembaban dengan kejadian DBD ini dikarenakan kondisi kelembaban yang hampir sama antara kelembaban di rumah responden yang menderita DBD dengan rumah responden yang tidak menderita DBD. Secara deskriptip rata-rata kelembaban yang didapatkan pada saat penelitian di rumah responden baik yang kasus maupun kontrol menujukan hasil yang sama yaitu $<60 \%$.

Secara teori kelembaban yang berkisar dari $60 \%-80 \%$ merupakan kelembaban yang optimal untuk membantu proses embriosasi dan ketahanan jentik nyamuk. Pada kelembaban yang kurang dari $60 \%$ umur nyamuk akan menjadi pendek karena akan berpengaruh pada sistem pernafasan nyamuk sehingga bila dalam kelembaban yang rendah makan akan menyebabkan penguapan pada tubuh nyamuk.

Kelembaban mempunyai pengaruh dalam perkembangbiakan jentik nyamuk Aedes aegypti namun tidak berpengaruh secara langsung dalam pada angka kejadian DBD. Seperti dalam penelitian Novitasari dan Sugiyanto ${ }^{16}$ bahwa kelembaban yang berkisar 70\%-90\% merupakan kelembaban yang optimal untuk perkembangbiakan jentik nyamuk. 
3) Hubungan antara pencahayaan dengan kejadian Demam Berdarah Dengue di wilayah kerja Puskesmas Kalasan Kabupaten Sleman

Tabel 4. Hasil Analisis Bivariat Hubungan antara Pencahayaan dengan Kejadian Demam Berdarah Dengue Di Wilayah Kerja Puskesmas Kalasan Kabupaten Sleman Tahun 2018

\begin{tabular}{lcccccc}
\hline \multirow{2}{*}{$\begin{array}{l}\text { Pencahaya } \\
\text { an }\end{array}$} & \multicolumn{4}{c}{ DBD } & \multicolumn{2}{c}{ Total } \\
\cline { 2 - 5 } & \multicolumn{2}{c}{ Kasus } & \multicolumn{2}{c}{ Kontrol } & & \\
\hline $\begin{array}{l}\text { Memenuhi } \\
\text { syarat }\end{array}$ & 5 & 62,5 & 23 & 95,8 & 28 & 87,5 \\
$\begin{array}{l}\text { Tidak } \\
\text { memenuhi } \\
\text { syarat }\end{array}$ & 3 & 37,5 & 1 & 4,2 & 4 & 12,5 \\
\hline Jumlah & 8 & 100 & 24 & 100 & 32 & $\begin{array}{r}100 . \\
0\end{array}$ \\
\hline p-value $=0,039$ OR $=0,072$ & & & &
\end{tabular}

Pada Tabel 4. menunjukan bahwa kondisi pencahayaan di rumah responden yang menderita DBD (kasus) lebih banyak yang memenuhi syarat perkembangbiakan dan pertumbuhan vektor yaitu 5 responden $(62,5 \%)$ dibandingkan dengan kondisi pencahayaan di rumah responden yang tidak memenuhi syarat perkembangbiakan dan pertumbuhan vektor yaitu 3 responden $(37,5 \%)$. Begitu juga dengan kondisi pencahayaan di rumah responden yang tidak menderita DBD (kontrol) banyak yang memenuhi syarat perkembangbiakan dan pertumbuhan vektor yaitu 23 responden (95.8\%) dibandingkan dengan kondisi pencahayaan di rumah responden yang tidak memenuhi syarat perkembangbiakan dan pertumbuhan vektor yaitu 1 responden $(4.2 \%)$.

Hasil uji statistik fisher diperoleh hasil analisis bivariat dengan nilai $\mathrm{p}<0,05$ yaitu 0,039 yang artinya ada hubungan yang bermakna secara statistik antara variabel pencahayaan dengan kejadian DBD. Nilai OR=0,072 dengan CI 95\% (0,006-0,849) yang artinya pencahayaan belum tentu merupakan faktor protektif terhadap kejadian DBD. Hasil penelitian ini sejalan dengan penelitian Ekel dkk17 dengan nilai $\mathrm{p}=0,002$ yang berarti ada hubungan antara pencahayaan dengan kejadian DBD di wilayah kerja Puskesmas Tikala Baru. Selain dari penelitian Ekel dkk17 dan beberapa penelitian lainnya pun juga memunjukan hasil yang sama seperti hasil penelitian yang dilakukan peneliti maupun penelitian dari Ekel dkk. ${ }^{17}$

Hal ini bisa disebabkan dari kebiasaan warga yang sebagian besar tidak membuka pintu ataupun jendela di pagi dan siang hari sehingga sinar matahari yang masuk kurang optimal. Selain itu keadaan rumah responden yang jarak yang cukup berdempetan juga mempengaruhi dari intensitas cahaya yang dapat masuk ke dalam rumah, serta masih banyaknya pepohonan disekitar rumah dan tanaman-tanaman hias yang berada di luar rumah juga yang menghalangi masukknya cahaya matahari. Hal ini memberikan peluang kepada nyamuk karena tempat yang minim cahaya akan dijadikannya sebagai tempat beristirahat.

Rumah dengan pencahayaan yang kurang serta ditambahnya dengan penghuni rumah yang padat dan memiliki kebiasan yang dapat mendukung perkembangbiakan dan penyebaran nyamuk Aedes aegypti dan ini juga diperkuat dengan hasil penelitian Purba $^{18}$ yang menyatakan cahaya merupakan faktor utama yang mempengaruhi nyamuk untuk beristirahat pada suatu tempat, bila intensitas cahaya rendah dan kelembaban yang tinggi maka kedua hal ini menjadikan kondisi yang baik untuk perkembanganan dan penyebaran nyamuk. Pada intensitas cahaya yang rendah nyamuk akan berterbangan serta larva nyamuk akan bertahan lebih lama di suatu ruangan dalam kontainer apabila keadaanya gelap.

\section{SIMPULAN}

Hasil analisis data dan pembahasan pada hubungan kondisi lingkungan fisik rumah dengan kejadian demam berdarah dengue di wilayah kerja Puskesmas Kalasan Kabupaten Sleman, maka dapat ditarik kesimpulan sebagai berikut 1)Ada hubungan antara ventilasi berkasa dengan kejadian demam berdarah dengue di wilayah kerja Puskesmas Kalasan Kabupaten Sleman. 2)Tidak ada hubungan antara kelembaban dengan kejadian demam berdarah dengue di wilayah kerja Puskesmas Kalasan Kabupaten Sleman. 3)Ada hubungan antara pencahayaan dengan kejadian demam berdarah dengue di wilayah kerja Puskesmas Kalasan Kabupaten Sleman Saran

\section{DAFTAR PUSTAKA}

1. Infodatin. Demam Berdarah Dengue. Pusat Data dan Informasi Kementerian Kesehatan RI. Jakarta; 2016

2. Rahman DA. Hubungan Kondisi Lingkungan Rumah dan Praktik 3M dengan Kejadian DBD di Wilayah Kerja Puskesmas Blora Kabupaten Blora. Unnes Journal of Public Health 2012, 1(2):1-7, ISSN 2252-6781

3. Kementrian Kesehatan Republik Indonesia. Profil Kesehatan Indonesia Tahun 2016. Kementrian Kesehatan RI. Jakarta: 2016

4. Adyatma, Ishak H, Ibrahim E. Hubungan Antara Lingkungan Fisik Rumah, Tempat Penampungan Air dan Sanitasi Lingkungan Dengan Kejadian DBD di Kelurahan Tidung Kecamatan Rappocini Kota Makassar, Bagian Kesehatan Lingkungan, FKM, Universitas Hasanuddin. Makasar; 2011, 110

5. Handoyo W, Hestiningsih R, Martin. Hubungan Sosiodemografi dan Lingkungan Fisik Dengan Kejadian Demam Berdarah Dengue (DBD) pada Masyarakat Pesisir Pantai Kota Tarakan (Studi Kasus Pada Daerah Buffer Kantor Kesehatan 
Pelabuhan Kelas II Tarakan), Jurnal Kesehatan Masyarakat 2015, 3(3):188-195, ISSN: 2356-3346.

6. Sari, E., Wahyuningsih, N.E., Murwani, R., Hubungan Lingkungan Fisik Rumah Dengan Kejadian Demam Berdarah Dengue Di Semarang, Jurnal Kesehatan Masyarakat (e-Journal) 2017, 5(5):609-618, ISSN: 2356-3346

7. Yudhastuti R, Vidiyani A.Hubungan Kondisi Lingkungan, Kontainer, dan Perilaku Masyarakat dengan Keberadaan Jentik Nyamuk Aedes aegypti Di Daerah Endemis Demam Berdarah Dengue Surabaya, Jurnal Kesehatan Lingkungan 2005, 1(2):170-182.

8. Susilani AT, Wibowo TA. Dasar-dasarMetodologi untuk Penelitian untuk Mahasiswa Kesehatan. Graha Cendekia, Yogyakarta; 2015.

9. Sugiyono. Metode Penelitian Kuantitatif, Kualitatif dan R\&D. Alfabeta. Bandung; 2009.

10. Ayun LL, Pawenang ET. Hubungan Antara Faktor Lingkungan Fisik dan Perilaku Dengan Kejadian Demam Berdarah Dengue (DBD) Di Wilayah Kerja Puskesmas Sekaran, Kecamatan Gunungpati, Kota Semarang, Public Health Perspective Journal 2017, 2(2):97-104.

11. Sari E, Wahyuningsih NE, Murwani R. Hubungan Lingkungan Fisik Rumah Dengan Kejadian Demam Berdarah Dengue Di Semarang, Jurnal Kesehatan Masyarakat (e-Journal) 2017, 5(5): 609-618,ISSN : 2356-3346.

12. Bangkele YE. Hubungan Suhu dan Kelembaban Dengan Kejadian Demam Berdarah Dengue (DBD) Di Kota Palu Tahun 2010-2014, Medika Tadulako, Jurnal Ilmiah Kedokteran 2016, 3(2):40-50.
13. Ridha MR, Rahayu N., Rosvita NA, Setyaningtyas ED. Hubungan Kondisi Lingkungan Dan Kontainer Dengan Keberadaan Jentik Nyamuk Aedes aegypti Di Daerah Endemis Demam Berdarah Dengue Di Kota Banjarbaru, Jurnal Epidemiologi dan Penyakit Bersumber Binatang (Epidemiology and Zoonosis Journal) 2013, 4(3):133-137.

14. Maria I, Ishak H, Selomo M. Faktor Risiko Kejadian Demam Berdarah Dengue (DBD) Di Kota Makassar Tahun 2013. Bagian Kesehatan Lingkungan, FKM, UNHAS. Makassar; 2013

15. Gafur A, Jastam MS. Faktor yang Berhubungan dengan Keberadaan Jentik Nyamuk Aedes aegypti di Kelurahan Batuan Kota Makassar Tahun 2015, Al-Sihah : Public Health Science Journal 2015, 7(1): 50-62.

16. Novitasari I, Sugiyanto Z. Hubungan Suhu, Kelembaban Rumah, Dan Perilaku Masyarakat Tentang PSN Dan Larvasida Dengan Keberadaan Jentik Nyamuk Penularan Demam Berdarah Dengue Di RW 01 Kelurahan Sendangguwo Semarang, Program Studi Kesehatan Masyarakat Universitas Dian Nuswantoro, 2013, 1-8

17. Ekel YL, Kepel BJ, Tulung M. Hubungan Antara Faktor Lingkungan Fisik Rumah Dengan Kejadian Penyakit Demam Berdarah Dengue (DBD) Di Wilayah Kerja Puskesmas Tikala Baru Manado, 2017, 1-16

18. Purba D. Pengaruh Faktor Lingkungan Fisik dan Kebiasaan Keluarga Terhadap Kejadian Demam Berdarah Dengue (DBD) di Kecamatan Binjai Timur Kota Binjai Tahun 2012, Thesis, Medan : Universitas Sumatera Utara 2012 